\title{
Customer-Based Brand Equity: The Evidence from China
}

\author{
Alex Y.-S. Lin \\ Beijing Institute of Technology, Zhuhai \\ E-Mail: alexlin218@gmail.com \\ Yu-Ting Huang \\ Sun Yat-sen University \\ E-Mail: hyouting@mail.sysu.edu.cn \\ Meng-Kai Lin \\ National Sun Yat-sen University \\ E-Mail: d006070006@student.nsysu.edu.tw
}

\begin{abstract}
Branding is one of the most dominant trends in the global hotel industry. This research aims to focus on customer-based brand equity, and examines whether brand equity influences customers' repurchase intention in the hotel industry in Zhuhai, China. A sample of 193 valid responses was received through face-to-face surveys of customers who had experienced staying in high-star hotels. The results of the survey were analysed using a linear regression model, and the preliminary results indicate that there was a positive and meaningful relationship between brand equity and repurchase intention. Furthermore, this research contributes both applied and theoretical outcomes with empirical evidence. The paper also outlines the limitations and directions for future research.
\end{abstract}

Keywords: Brand Equity, Repurchase Intention, Hotel, Zhuhai 


\section{INTRODUCTION}

Branding is one of the most dominant trends in the global hotel industry, where building brand equity or strong brands has a significant influence on a hotel's prospects of success. The key reason for achieving hotel success is that it could help differences in the product, the premium for employees, maintaining customer loyalty, and increasing their repurchase behaviour (Keller, 2001). The literature on brand equity has proposed numerous reasons for the growth of branding within the hotel industry (e.g., Bowen and Shoemaker, 1998; Ishaq, Hussain, Asim, and Cheema, 2014; Kim and Kim, 2005). From a corporate strategy viewpoint, for example, key arguments have focused on the capability of charging a price premium over and above high-stars hotels, and the ability to retain customers by building brand loyalty (French and Smith, 2013; Sangster, Wolton, and McKenney, 2001). At one end of the brand concept is the simple idea that the level of customer satisfaction goes up as revenue per guest room goes up. On the other hand, the level of customer satisfaction goes down as the growth rate in room revenues decreases (Tsang and Qu, 2000).

This relationship between brand equity and consumers is built as consumers get to know a brand, even if they initially choose accommodation randomly, use its facilities, evaluate their experience, and then begin the relationship. The brand represents consumers' experience with its organisation. The intense competitive landscape has been linked to the perspective of brand equity, whereas satisfaction with compliant handing has a significant impact on trust and commitment (Tax, Brown, and Chandrashekaran, 1998). Furthermore, brand equity could provide memorable experiences to customers rather than selling services only (Gilmore and Pine, 2002). Finally, customers have a deeply embedded image of the brand, and opt to repeat their experience by choosing the same brand. Overall, a hotel brand displays a relationship with customers.

Zhuhai is one of six special economic zones in China that has developed rapidly, especially the tourism and accommodation industry. Between 2006 and 2011, Zhuhai's GDP increased from $\$ 74.646$ billion to $\$ 140.324$ billion, an increase of $88 \%$ (Finance Bureau of Zhuhai, 2014). After 2010, economic growth slowed down. However, Zhuhai still has the biggest amount of social financing all over China. Among the factors supporting Zhuhai's economic growth is its favourable geographic location for tourists. According to the Finance Bureau of Zhuhai (2014), in 210 overnight visitors to Zhuhai numbered 13.8 million, while in 2011, this figure grew to 15.36 million (an increase of 11.2\%). Overnight visitors consisted mainly of domestic 
tourists. Secondly, in recent years, more and more accommodations have been built in Zhuhai, especially hotel chains and/or high-star hotels.

This study investigates whether brand equity influences customers' repurchase intention in China. To the best of our knowledge no related research focuses on China's hotel industry. In this study, we argue that hotel customers' perceptions of brand equity are an antecedent to their repurchase intention. As far as the authors are aware (Keller, 1993; Sangster et al., 2001), there is a lack of evidence in the brand equity literature regarding the relationship between brand equity and customer repurchasing decision, specifically in relation to the definition of hotel brand equity, customer perceptions, and the operation of brand equity in China's hotel industry. For this reason, this research focuses on exploring a theory of brand equity, and specifically the literature on hotel brand equity in the context of China's hotel industry. Furthermore, this research contributes both applied and theoretical outcomes with empirical evidence to show how hotel brand equity applies to customers' repurchasing decisions.

\section{LITERATURE REVIEW}

A brand can be defined as "a name, term, sign, symbol, or design, or combination of them which is intended to identify the goods and services of one seller or group of sellers and to differentiate them from those of competitors" (Kotler, 1991, p. 442). Brand equity has attracted much attention from marketing academics and practitioners due to its significant role as an important invisible firm asset (Aaker, 1991; Keller, 2003). Keller and Lehmann (2006) stated that brands simplify customer choices, promise a particular level of quality, engender trust, and reduce risk. Keller (2003) indicated that brand equity was the added value resulting in different marketing outcomes, a common denominator for explaining marketing strategies, and the value of a brand that could be constructed in many ways. In the overview of these characteristics, brand equity is defined here by brand-use satisfaction as repurchasing, the price paid for perceived superior value, and the particular brand as a particular customer group. Comprehending the content and structure of brand equity is critical because they influence what comes to mind when a customer thinks about a brand in response to marketing activity for that brand.

To develop a better scale, the current study examines previous research, which argues that brand equity is multi-dimensional. Such research has been broadly accepted and employed by many researchers (Keller, 1993; Huang and Sarigöllü, 2012; Low and Lamb, 2000; Motameni and Shahrokhi, 1998; Prasad and Dev, 2000; 
Yoo and Donthu, 2001; Zhanga, van Doornb, and Leeflang, 2014), who have made the following reviews.

\section{Perceived Brand Quality}

The first dimension distinguishing brand equity is perceived brand quality. Perceived quality is defined as the customer's perception of the overall quality in relation to the intended purpose of choosing a product or experiencing a service (Zeithaml, 1988). In a similar manner to Lassar, Mittal, and Sharma's (1995) study, Mittal and Kamakura (2001) identify perceived quality as a component of brand equity. The customer's subjective judgement of quality could be influenced by personal product experiences, unique needs, and consumption situations (Mittal and Kamakura, 2001; Lassar et al., 1995). Moreover, Kotler (1991) draws attention to the intimate connection between perceived brand quality and product and service quality, customer satisfaction, and organisational profitability. In other words, perceived quality is a competitive requisite, and many organisations today have turned customeroriented quality into a potent strategy (Dube and Renaghan, 1999; Huang and Sarigöllü, 2012; Kumar, Dash, and Purwar, 2013). Therefore, high perceived quality means that through long-term experience related to the brand, customers will recognise the difference and superiority of the brand and choose it rather than other competing brands.

\section{Brand Awareness and Image}

A large number of brand equity studies are examined mainly on the conceptual constructs proposed by management (e.g., Rust, Lemon, and Zeithaml, 2004; Tsang and Qu, 2000; Zeithaml, Berry, and Parasuraman, 1996). Keller (1993) focused on two approaches, brand awareness and brand image, to measure customer-based brand equity, while Aaker (1991) emphasized that brand equity has many dimensions, including brand awareness. Keller (1993) proposed that "brand awareness relates to the likelihood that a brand name will come in mind and the ease with which it does so," and "brand image is defined here as perceptions about a brand as reflected by the brand associations held in consumer memory." Brand awareness consists of brand recognition and brand recall performance. The relative importance of brand recall and recognition depends on the extent to which consumers make decisions in and/or outside the store, among other factors (Battistoni and Colladon, 2013; Bettman 1979; Biel, 1992; Rossiter and Percy, 1987). Brand awareness contributes to brand equity for experienced customers, but not to the same degree (Prasad and Dev, 2000; Uslu, Durmuş, and Kolivar, 2013). Very simply, brand recognition is the process through 
which consumers correctly distinguish the brand as having been seen or heard, and brand recall requires that customers correctly generate the brand from memory.

Brand awareness has an effect on customer decision making in that it influences the formation and strength of brand associations with the brand image. An essential condition for the creation of a brand image is that a brand node is established in the customer's memory, and the nature of that brand node should affect how easily different kinds of information can become attached to the brand in the customer's memory. Moreover, brand awareness with strong associations forms a specific brand image. Brand image is tailored to the needs and wants of a target market using the marketing mix of product, price, place, and promotion (Dobni and Zinkhan, 1990; Kumar, et al., 2013). In other words, brand image, broadly speaking, is within the remit of marketers, and brand value has been considered largely an accounting issue (Huang and Sarigöllü, 2012; Perasad and Dev, 2000).

\section{Brand Uniqueness}

Brand positioning can lead to a sustainable competitive advantage or "unique selling proposition" for the brand that gives customers a compelling reason to buy that particular brand (Lasser et al., 1995). Brand uniqueness is defined as an antecedent of brand passion, although conceptually, this element is considered a dimension of consumer's affect (Li, Li, \& Kambele, 2012). Several authors strongly indicated that the uniqueness of the brand exceeds over other brands is critical to a brand's success (Kim and Kim, 2005; Netemeyer et al., 2004). For instance, customers might expect a suitable hotel to provide clean and comfortable accommodation with a strong infrastructure that can serve the needs of successive lodgers through the years. Customers may also believe Tripadvisor.com or some other leading travel advisory brand represents good information. Similarly, customers might expect an airline company to provide a safe flight, offer a variety of services, and so on, and they might consider a top-ranking airline, such as Singapore Airlines, to be the best example of an airline company. Thus, in almost all cases, kinds of categories of products that are linked to the brand are different to other brands. It is not surprising to note that the strength of the product category is a significant element of brand uniqueness (Chekalina, Fuchs, and Lexhagen, 2014; Lasser et al., 1995).

In spite of the increasing importance of the brand equity concept (Keller and Lehman, 2006; Kim and Kim, 2005), an instrument to measure brand equity from a customer perspective has been lacking. Moreover, several customer-based researches have suggested that measures of customer-based brand perceptions are accurate reflections of brand performance in the marketplace (Chekalina, et al, 2014; Lasser et 
al., 1995). Customer-based brand equity, in this respect, is the driving force behind incremental financial gains to the firm (Lasser et al., 1995). Based on the literature of brand equity reviewed, the definition of brand equity adopted for this study is "brand equity is a brand's power derived from the goodwill and name recognition which reflect consumer response to the marketing of the brand by perceived brand quality, brand awareness, brand image, and brand uniqueness." In the same manner, the quality, awareness, image, and uniqueness of brand associations are the dimensions distinguishing brand equity. Hence, this research aims to focus on customer-based brand equity (see Figure 1).

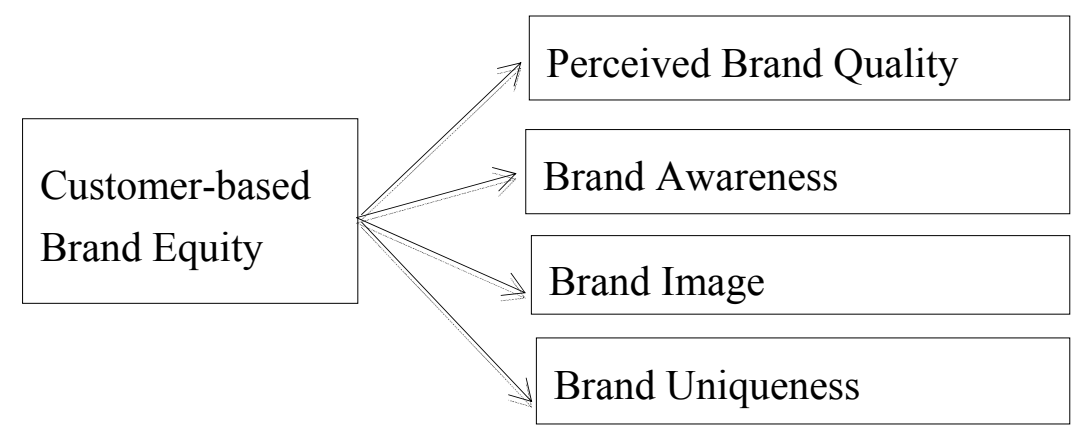

Figure 1 The Framework of Brand Equity

\section{The Relationship between Brand Equity and Repurchase}

The brand becomes an extension of the customer, a statement the customer can make to the words to explain. Brand equity for a hotel could be considered as having several advantages, such as purchase intentions (Chekalina, et al., 2014; Yi and Alison, 2001) and share value (Bailey and Ball, 2006). It is the factor that may prompt a consumer to book a room that has attributes and price similar to those of a room in another hotel. This brand equity is a combination of factors, such as perceived brand quality, brand awareness, brand image, and brand uniqueness concerning the hotel and its facilities. Positive customer experiences should contribute to positive attitudes towards the brand and thus bring the advantage of more consumer purchase intentions to the hotel (Cobb-Walgren, Ruble, and Donthu, 1995; Myers, 2003).

\section{Repurchase Intention and its Antecedents}

Researches have concentrated primarily on the determinants related to repurchase intention (Mittal and Kamakura, 2001), especially the relationship between customer loyalty and repurchase intention (Lai and Vinh, 2013; Yu and Alison, 2001). Repurchase intention is the individual's judgment about buying a designated service 
from the same company again (Chekalina, et al., 2014; Hellier, Geursen, Carr, and Richard, 2003). Similarly, repurchase intention is considered as the future purchase preference for a brand's products or services, and the positive intention to repurchase and recommend the brand to others (Hellier et al., 2003; Zeithaml et al., 1996).

Repurchase intention as a reflection of repurchase behaviour is decided by a customer's personal characteristics (Mittal and Kamakura, 2001). The misunderstanding of customers' psychological perceptions may damage the power of customer retention and loyalty (Yi and Alison, 2001). This has been confirmed by Wilson (1981), who proposed that the higher a product or service is in the consumer's mind, the higher the purchase intention and higher the last reported purchase of the brand is. Several researchers have indicated that customer satisfaction, substitute quality, and switching cost are the main variables that influence customers' repurchase intention (Hellier et al., 2003; Hocutt, 1998). Yi and La's (2004) research has shown that repurchase intention is affected by personality and brand as well as customer satisfaction, perceived quality, perceived value, demographic characteristic, and so on. Hence, the purpose of this research is to examine whether brand equity influences a customer's repurchase intention. The hypotheses for this research are as follows (see Figure 2):

$\mathrm{H}_{1}$ : Perceived brand quality positively impacts customer's repurchase intention.

$\mathrm{H}_{2}$ : Brand awareness positively impacts customer's repurchase intention.

$\mathrm{H}_{3}$ : Brand image positively impacts customer's repurchase intention.

H4: Brand uniqueness positively impacts customer's repurchase intention.

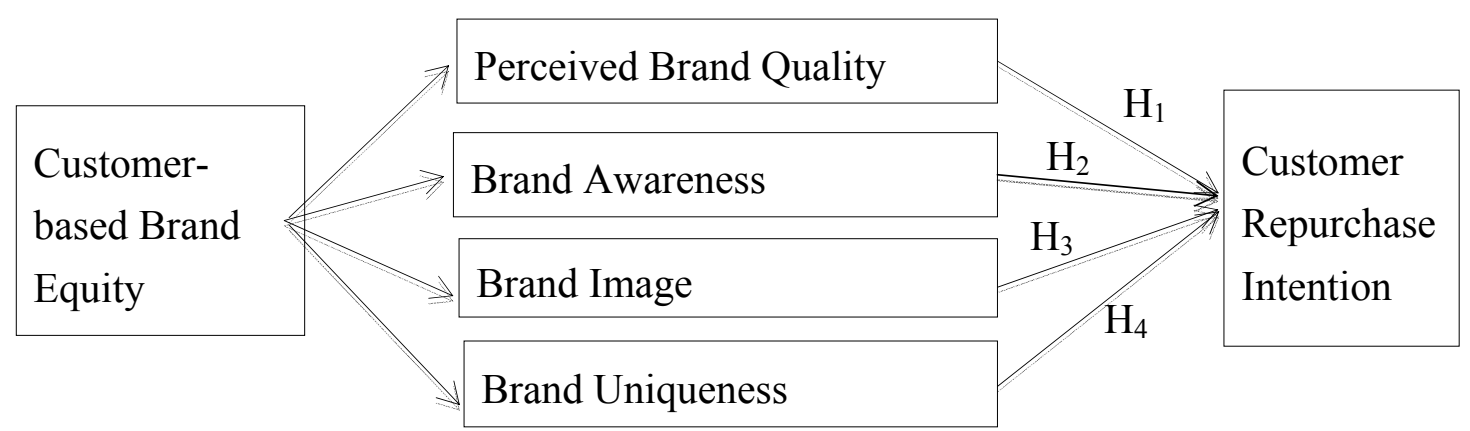

Figure 2 The Framework of This Study 


\section{METHODOLOGY}

\section{Questionnaire Design}

A questionnaire, which included Likert and forced-choice scales, was developed for this study. The purpose of this quantitative research was to describe and measure factors of brand equity and explain whether brand equity impacts customer repurchase intention from the customer's point of view. The literature identified three constructs as proposed dimensions of brand equity, and the previous section defined these constructs (Netemeyer, 2004). The Chinese questionnaire consists of three parts. Part 1 deals with the measurement of brand equity. Part 2 includes a five-item measurement of repurchase intention. Scale development for brand equity is outlined in Netemeyer's (2004) study. Both of these parts aim to examine how brand equity influences customers' repurchase behaviour and therefore attempts to understand their attitude and mentality. These items were rated on a 5-point Likert scale, with responses ranging from do not agree much (1) to agree a lot (5). Finally, Part 3 of the online survey captured employee demographics (see Table 1 for key demographic variables).

The intercept survey yielded 229 responses during April and May 2014, including 23 from survey participants who did not have much experience staying in high star-rated hotels. Data was cleaned to ensure integrity, with 13 respondents omitted from the study due to low-quality data. The useable response rate was $89 \%$. The final sample consisted of 193 Chinese respondents, a level deemed appropriate for data analysis.

\section{Data Analysis}

Based on the results, this research conducted SPSS 21.0 by using reliability analysis and a linear regression model. Reliability is a measure of how well measurement errors are minimised over time or how well a scale will accurately reflect the constructs intended over time; hence, it is the opposite of measurement error (Hair, Black, Babin, and Anderson, 2010). Error in the results shows the extent of measures or items that do not measure the same factor. For Likert scale measures, the generally agreed upon lower limit for Cronbach's alpha is 0.70 (Pallant, 2005). Moreover, an item-to-total correlation value less than 0.30 indicates that the corresponding item does not correlate very well with the scale overall and can be considered for deletion (Churchill, 1979).

Multiple linear regression analysis is used widely to evaluate how an outcome or response variable $(\mathrm{Y})$, involving brand quality, brand awareness, brand image, and 
brand uniqueness, is related to a set of predictors $\left(X_{1}, X_{2}, \ldots, X_{p}\right)$, and one dependent variable $Y$ refers to repurchase intention.

A linear model with an intercept can be written as

$$
\gamma_{i}=\beta_{0}+x_{i 1} \beta_{1}+\cdots+x_{i p} \beta_{p}+e_{i}
$$

The response of object $i$ is modelled as a linear function of regressor values $\chi_{i l}, \ldots, \chi_{\mathrm{ip}}$, with unknown coefficients $\beta_{1}, \ldots, \beta_{p}$, and ei represents the unexplained part.

Where $\beta \mathrm{j}$ is the population regression coefficient associated with the predictor $(\chi$ $\mathrm{j}$ ), and where $e$ is the random error with mean zero and a variance $\sigma 2$. Therefore, the model can provide a probability of response for everyone in the file, given the estimated parameters for a set of predictor variables. Such a method is used in this study to explore whether brand equity influences repeat purchase intention.

Table 1 Respondent Characteristics for The Sample $(\mathrm{n}=193)$

\begin{tabular}{lcc}
\hline \multicolumn{1}{l}{ Age } & Male $\%(\mathrm{n}=95)$ & Female $\%(\mathrm{n}=98)$ \\
\hline 24 \& below & 6.5 & 14.0 \\
\hline $25-34$ & 19.4 & 22.6 \\
\hline $35-44$ & 11.8 & 6.5 \\
\hline $45-54$ & 9.7 & 7.5 \\
\hline $55 \&$ over & 1.1 & 1.1 \\
\hline Education Level & & \\
\hline High school \& below & 8.6 & 4.3 \\
\hline Bachelor degree & 31.2 & 38.7 \\
\hline Post-graduate degree & 8.6 & 8.6 \\
\hline Income & & 6.5 \\
\hline 5,000 \& below & 19.4 & 24.7 \\
\hline $5,001-10,000$ & 19.4 & 7.5 \\
\hline $10,001-20,000$ & 8.6 & 6.5 \\
\hline $20,001-30,000$ & 2.2 & 3.2 \\
\hline $30,001 \&$ over & 2.2 & \\
\hline Frequency of staying in high-stars hotel & & 30.1 \\
\hline $1-3$ & 28.0 & 15.1 \\
\hline $4-6$ & 11.8 & 3.2 \\
\hline $7-9$ & 2.2 & 3.2 \\
\hline $10 \&$ above & 6.5 & \\
\hline
\end{tabular}

\section{Results}

The sample characteristics are reported in Table 1. A wide range of subjects representing a variety of backgrounds, demographics, education, and experience was 
surveyed. A majority of respondents were females who possessed a bachelor's degree. Almost all of the respondents $(70 \%)$ earned below $\$ 10,000$ per month. Nearly 60 per cent of the respondents had stayed in high-star hotels 1-3 times per year.

\section{Reliability Analysis}

We performed a reliability analysis on 12 items to assess the dimensionality of brand equity and five items for repurchase intention measure. As reported in Table 2, there is reliability among the four dimensions of brand equity, with Cronbach's alpha ranging from $\alpha=0.58$ to $\alpha=0.83$. Table 2 also shows that the item-to-total correlation is within an acceptable range as the item-to-total correlations are greater than the threshold of 0.30 . However, the reliability of brand quality scale was below $0.7(\alpha=$ 0.58 ), which resulted in brand quality scale being deleted; this means brand quality scale cannot be explained. Furthermore, Hypothesis 1 cannot be examined in this study. Hence, the results demonstrate that there are three dimensions of brand equity, including brand awareness, brand image, and brand uniqueness.

Table 2 The results of factor analysis $(n=193)$

\begin{tabular}{lll}
\hline Items & Mean $(\mathrm{SD})$ & Corrected item-to-total correlation \\
\hline Brand quality $(\boldsymbol{\alpha}=\mathbf{0 . 5 8})$ & \\
\hline BQ2 & $3.81(0.58)$ & 0.426 \\
BQ3 & $3.60(0.69)$ & 0.408 \\
BQ1 $3.38(0.82)$ & 0.373 \\
\hline Brand awareness $\quad(\boldsymbol{\alpha}=\mathbf{0 . 8 3})$ & \\
\hline BA2 $3.46(0.90)$ & 0.730 \\
BA3 & $3.42(0.89)$ & 0.647 \\
BA1 $3.32(0.87)$ & 0.708 \\
\hline Brand image $(\boldsymbol{\alpha}=\mathbf{0 . 8 3})$ & \\
\hline BI3 $3.66(0.85)$ & 0.725 \\
BI2 $3.61(0.93)$ & 0.777 \\
BI1 $3.48(0.90)$ & 0.585 \\
\hline Brand uniqueness $\quad(\boldsymbol{\alpha}=\mathbf{0 . 7 0})$ & \\
\hline BU1 & $3.88(0.64)$ & 0.354 \\
BU3 & $3.87(0.71)$ & 0.616 \\
BU2 & $3.62(0.74)$ & 0.609 \\
\hline Repurchase intention $(\boldsymbol{\alpha}=\mathbf{0 . 7 2})$ \\
\hline RI2 $3.86(0.79)$ & 0.638 \\
RI1 $3.68(0.71)$ & 0.481 \\
RI4 & $3.62(0.77)$ & 0.681 \\
RI5 & $3.62(0.79)$ & 0.717 \\
RI3 & $2.72(0.99)$ & 0.305 \\
\hline
\end{tabular}


Moreover, Table 2 demonstrates that the items for repurchase intention had an acceptable level of reliability $(\alpha=0.72)$. This is acceptable following the threshold of Nunnally and Bernstein (1994). The item-to-total correlations were calculated for the repurchase intention scale. Finally, Table 2 shows that the item-to-total correlation is within an acceptable range as the item-to-total correlations are greater than the threshold of 0.30 . Hence, a clear five-item structure is supported.

Table 3 shows the correlation matrix of both brand equity and repurchase intention. The correlation results indicate that both repurchase intention and brand equity are significantly $(\mathrm{p}<0.05)$ correlated with brand quality, brand awareness, brand image, and brand uniqueness.

Table 3 correlation matrix

\begin{tabular}{lllll}
\hline & Brand Awareness & Brand Image & $\begin{array}{l}\text { Brand } \\
\text { Uniqueness }\end{array}$ & $\begin{array}{l}\text { Repurchase } \\
\text { Intention }\end{array}$ \\
\hline Brand Awareness & 1 & & & \\
\hline Brand Image & $.320^{*}$ & 1 & & \\
\hline Brand Uniqueness & .142 & $.318^{*}$ & 1 & 1 \\
\hline Repurchase Intention & $.286^{*}$ & $.420^{*}$ & $.535^{*}$ & 1 \\
\hline
\end{tabular}

*Correlation is significant at the 0.05 level (two-tailed).

The regression analysis results relating to brand awareness are a significant determinant of brand equity (see Table 4). As the table indicates, brand awareness is a significant $(\mathrm{p}<0.05)$ determinant of brand equity, and influences customers. Thus, Hypothesis 2 is supported. It can be concluded that brand awareness has a significant positive influence on customers' repurchase intention. The adjusted $\mathrm{R}^{2}$ for this regression is 0.072 , indicating that this dimension accounts for $7 \%$ of the variance in repurchase intention. The regression analysis results for Hypothesis 3 relating to brand image also appear in Table 4 . The adjusted $\mathrm{R}^{2}$ for this regression is 0.167 , indicating that the dimension of brand image accounts for over $16 \%$ of the variance in repurchase intention. The regression results reveal that brand image is a significant and direct predictor of repurchase intention, as hypothesised. Therefore, Hypothesis 3 is supported. Furthermore, brand uniqueness was a significant predictor of repurchase intention. The regression of brand uniqueness on repurchase intention resulted in the following regression equation, $Y^{\prime}=0.573+.278 X$. Adjusted R-squared was .278 ; in other words, about $27 \%$ of the variability in repurchase intention was explained by brand uniqueness. Thus, Hypothesis 4 is supported. 
Table 4 Regression analysis

\begin{tabular}{lcc}
\hline Independent Variables & Beta & $t$-value \\
\hline Brand Awareness & 0.219 & $2.847^{*}$ \\
\hline Adjusted $\mathrm{R}^{2}=0.072, F=8.105,(p=0.005)$ \\
\hline Brand Image & 0.319 & $4.418^{*}$ \\
\hline Adjusted $\mathrm{R}^{2}=0.167, F=19.485,(p=0.000)$ \\
\hline Brand Uniqueness & 0.573 & $6.041^{*}$ \\
\hline Adjusted $\mathrm{R}^{2}=0.278, F=36.488,(p=0.000)$ \\
\hline *Significant at the 0.05 level.
\end{tabular}

\section{DISCUSSION AND CONCLUSION}

The previous section presented the results obtained in this study. This section positions the results in terms of theory to clearly articulate the contribution the current research makes to the literature. The literature review presented a wide range of ideas that could be considered under the term "brand equity" (Aaker, 1991; Keller, 1993). The results supported Hypotheses 2-4, which is consistent with previous results. Several authors (see Keller, 2003; Lasser et al., 1995) provide a theoretical foundation and conceptual framework, based on brand equity variables, involving brand awareness, brand image, and brand uniqueness. Moreover, numerous prior studies have confirmed the relationship between brand equity and customer repurchasing decision (Chekalina, et al., 2014; Hellier et al., 2003). As the regression results indicate, brand equity is vital to the level of repurchase intention, which in turn can often lead to more customer loyalty. The current study provides researchers with a useful tool for measuring various dimensions of brand equity through the customers' viewpoint. Of course, organisations have to create their own brand equity in order to increase their competitive strength, as they might be able to rely upon the differences of brand to segment other brands (Yi and Alison, 2001). Still, whether or not there is reliance on brand awareness, brand image, or brand uniqueness, brand equity is critical (Biel, 1992; Netemeyer et al., 2004; Yoo and Donthu, 2001).

Organisations increase the level of customers' repurchase intention by using the differences in brand equity, which proves once again that brand equity is a useful tool (Aaker, 1996; Prasad and Dev, 2000). Brand equity is thus established for customers. As a result, questionnaires should be based on customers' views. Several studies in the brand equity literature have targeted customers to understand whether brand equity is critical for them (Lasser et al., 1995; Zeithaml, 1988). Similarly, this research targeted customers who have high-star hotel staying experience, and confirmed customers' perceptions and opinions about brand equity. The results reveal that brand equity 
significantly influences customers' repurchase intention. In supporting this view, Hocutt's (1998) study found that the elements of brand equity have exert different degrees of influence on customer repurchase intention. The current study hence provides researchers with a useful tool for measuring various dimensions of brand equity.

\section{Implications for Management}

The results of the current study have implications for the hotel industry in terms of brand equity and customers' repurchase intention. For example, the results suggest that hotel management and strategy benefit from understanding the importance of brand equity in order to further improve the degree of customers' repurchase intention, and hence customer loyalty. Where brand equity is of a low value, an organisation should strengthen it to improve the degree of customers' repurchase intention. There could be a case, for example, in which projecting brand image through advertising is essential to influence customers' repurchasing decisions. Placing such advertisements regularly would be particularly useful, say, for hotel managers trying to establish an appropriate channel to project a more comprehensive image of the brand for the customer. A baseline measurement would be used to assess which brand equity is meeting the customers' needs and perceptions about the extent of the brand equity currently being undertaken to identify room for improvement.

\section{Limitations and Future Research}

This study has illustrated whether brand equity influences customer repurchase intention. However, the reliability of brand quality was questionable in the study, which has limitations, including a relatively low response rate. Future research would stimulate more research attention by collecting a larger, more representative sample. Expanding the research framework by examining and identifying the multiple dimensions that could enhance the existing relationship between brand equity and repurchase intention would improve the reliability and validity of the brand equity scales. The result of brand quality in this study was not reliable. As mentioned, almost $70 \%$ of the respondents earned less than $\$ 10,000$. However, hotel brand should be considered by participants who can afford the prices of high-star hotels. A future study should be conducted with a conditional question that asks participants' consumption and economic capacity to clear the quality of participants. Moreover, the percentage of explained variance was low for at least one of the regressions. The extent to which the Chinese hotel industry - a diverse-brand environment - has succeeded in doing by only simple demographic information remains questionable. Future studies should 
collect more demographic information on customers to understand the extent to which customers differentiate brand equity.

\section{REFERENCES}

Aaker, D.A. (1991). Managing brand equity: Capitalizing on the value of a brand name. The Free Press, New York.

Aaker, D.A. (1996). Measuring brand equity across products and markets. California Management Review, 38(3) , 102-120. http://dx.doi.org/10.2307/41165845

Bailey, R. and Ball, S. (2006). An exploration of the meanings of hotel brand equity. The Service Industries Journal, 26(1) , 15-38. http://dx.doi.org/10.1080/02642060500358761

Battistoni, E. and Colladon, A. F. (2013) Prominent determinants of consumer-based brand equity. International Journal of Engineering Business Management, 5(25), 1-8. http://dx.doi.org/10.5772/56835

Bettman, J.R. (1979). An information processing theory of consumer choice. MA: Addison Wesley Publishing Company. http://dx.doi.org/10.2307/1250155

Biel, A.L. (1992). How brand image drives brand equity, Journal of advertising research, 32(6), 6-12.

Bowen, J.T. and Shoemaker, S. (1998). Loyalty: a strategic commitment. Cornell Hotel and Restaurant Administration Quarterly, 39(1), 12-25. http://dx.doi.org/10.1177/001088049803900104

Chekalina, T., Fuchs, M. and Lexhagen, M. (2014). A value co-creation perspective on customer-based brand equity model for tourism destinations-a case from Sweden. Finnish Journal of Tourism Research, 10(1), 8-24.

Churchill, G.A. (1979). A paradigm for developing better measures of marketing constructs. Journal of Marketing Research, 16(2), 64-73. http://dx.doi.org/10.2307/3150876

Cobb-Walgren, C. J., Ruble, C. A. and Donthu, N. (1995). Brand equity, brand preference, and purchase intent. Journal of Advertising, 24(3), 25-40. http://dx.doi.org/10.1080/00913367.1995.10673481 
Dobni, D. and Zinkhan, G. M. (1990). In search of brand image: A foundation analysis. in advances in consumer research, 17(1),110-119. Marvin E. Goldberg, Gerald Gorn, and Richard W. Pollay, eds. Provo UT: Association for consumer research.

Finance Bureau of Zhuhai (2014). Zhuhai Government Annual Report. Retrieve from http://zwgk.zhuhai.gov.cn/index3.html

French, A. and Smith, G. (2013). Measuring brand association strength: a consumer based brand equity approach. European Journal of Marketing, 47(8), 1356 -1367. http://dx.doi.org/10.1108/03090561311324363

Dube, L. and Renaghan, L.M. (1999). Sustaining competitive advantage. Cornell Hotel and Restaurant Administration Quarterly, 40, 27-33.

Gilmore, J. H., \& Pine, B. J. (2002). Differentiating hospitality operations via experiences: Why selling services is not enough. The Cornell Hotel and Restaurant Administration Quarterly, 43(3), 87-96. http://dx.doi.org/10.1016/S0010-8804(02)80022-2

Hair, J.F., Black, W.C., Babin, B.J. and Anderson, R. (2010). Multivariate data analysis. USA: Prentice Hall.

Hellier, P.K., Geursen, G.M., Carr, R.A. and Rickard, J.A. (2003). Customer repurchase intention: A general structural equation model. European journal of marketing, 37(11), 37(12), 1762-1800. http://dx.doi.org/10.1108/03090560310495456

Hocutt, M.A. (1998). Relationship dissolution model: antecedents of relationship commitment and the likelihood of dissolving a relationship. International Journal of Service Industry Management, 9(1), 189-200. http://dx.doi.org/10.1108/09564239810210541

Huang R. and Sarigöllü, E. (2012). How brand awareness relates to market outcome, brand equity, and the marketing mix. Journal of Business Research, 65(1), 92-99. http://dx.doi.org/10.1016/j.jbusres.2011.02.003 
Ishaq, M. I., Hussain, N., Asim, A.I., Cheema, L.J. (2014). Brand equity in the Pakistani hotel industry. Revista de Administração de Empresas, 54(3), 284-290. http://dx.doi.org/10.1590/S0034-759020140304

Keller, K.L. (1993). Conceptualising, measuring, and managing consumer-based brand equity. Journal of Marketing, 57(1), 1-22.

Keller, K.L. (2001). Building customer-based brand equity. Marketing Management, 10(2), 14-21.

Keller, K.L. (2003). Strategic brand management: building, Measuring, and Managing Brand Equity, (2nd ed). Upper Saddle River, NJ: Prentice Hall.

Keller, K.L. and Lehmann, D.R. (2006). Brands and branding: research findings and future priorities. Marketing $\quad$ Science, 25(6), 740-759. http://dx.doi.org/10.1287/mksc. 1050.0153

Kim, H.B. and Kim, W.G. (2005). The relationship between brand equity and firms performance in luxury hotels and chain restaurants. Tourism management, 26(4), $549-560$.

Kotler, P.H. (1991). Marketing management: analysis, planning, and control. (8th ed.) Englewood Cliffs, NJ: Prentice-Hall, Inc.

Kumar, R.S., Dash, S. and Purwar, P.C. (2013). The nature and antecedents of brand equity and its dimensions. Marketing Intelligence and Planning, 31(2), 141 - 159. http://dx.doi.org/10.1108/02634501311312044

Lai, W.-H. and Vinh, N.Q. (2013). Online promotion and its influence on destination awareness and loyalty in the tourism industry. Advances in Management and Applied Economics, 3(3), 15-30.

Lassar, W., Mittal, B., \& Sharma, A. (1995). Measuring customer-based brand equity. The Journal of Consumer Marketing, 12(40), 11-19. http://dx.doi.org/10.1108/07363769510095270

Li, G.X., Li, G.F., \&Kambele, Z. (2012). Luxury fashion brand consumers in China: perceived value, fashion lifestyle, and willingness to pay. Journal of Business Research, 65(10), 1516-1522. http://dx.doi.org/10.1016/j.jbusres.2011.10.019 
Low, G.S. and Lamb, C.W. (2000). The measurement and dimensionality of brand associations. Journal of Product and Brand Management, 9(6), 350 - 368. http://dx.doi.org/10.1108/10610420010356966

Mittal, V. and Kamakura, W.A. (2001). Satisfaction, repurchase intent, and repurchase behavior: investigating the moderating effect of customer characteristics, Journal $\begin{array}{llll}\text { of } \quad \text { Marketing } \quad \text { Research, } & \text { 131-142. }\end{array}$ http://dx.doi.org/10.1509/jmkr.38.1.131.18832

Motameni, R. and Shahrokhi, M. (1998). Brand equity valuation: a global perspective. Journal of Product and Brand Management, 7(4), 275-290. http://dx.doi.org/10.1108/10610429810229799

Meyer, J. P. and Allen, N. J. (1991). A three-component conceptualization of organizational commitment. Human Resources Management Review, 1(1), 61-98. http://dx.doi.org/10.1016/1053-4822(91)90011-Z

Netemeyer, R.G., Krishnan, B., Pullig, C., Wang, G., Yagci, M., Dean, D., ... \& Wirth, F. (2004). Developing and validating measures of facets of customer-based brand equity. Journal of Business Research, 57(2), 209-224. http://dx.doi.org/10.1016/S0148-2963(01)00303-4

Nunnally, W.L. and Bernstein, I.H. (1994). Psychometric theory. Sydney: McGraw Hill.

Pallant, J. (2005). SPSS survival manual: A step by step guide to data analysis using SPSS, (12th en.). Chicago, IL: Open University Press.

Prasad, K. and Dev. C.S. (2000). Managing hotel brand equity: a customer-centric framework for assessing performance. Cornell Hotel and Restaurant Administration Quarterly, 22-31. http://dx.doi.org/10.1177/001088040004100314

Rossiter, J. and Percy L. (1987). Advertising and promotion management. New York: McGraw-Hill Book Company. 
Rust, R.T., Lemon, K.N. and Zeithaml, V.A. (2004). Return on marketing: using customer equity to focus marketing strategy. Journal of marketing, 68(1), 109127. http://dx.doi.org/10.1509/jmkg.68.1.109.24030

Tax, S. S., Brown, S. W. and Chandrashekaran, M. (1998). Customer evaluations of service complaint experience: implications for relationship marketing. Journal of Marketing, 60-75. http://dx.doi.org/10.2307/1252161

Tsang, N. and Qu, H. (2000). Service quality in Chinas hotel industry: a perspective from tourists and hotel managers. International Journal of Contemporary Hospitality Management, $\quad$ 316-326. http://dx.doi.org/10.1108/09596110010339706

Sangster, A., Wolton, J. and McKenney, S. (2001). The international hotel industrycorporate strategies and global opportunities. Travel and Tourism Intelligence, London.

Uslu, A., Durmuş, B. and Kolivar, B.K. (2013). Analyzing the brand equity of Turkish airlines services: comparing the Japanese and Turkish perspectives. Social and Behavioral Sciences, 99(6), 446-454. http://dx.doi.org/10.1016/j.sbspro.2013.10.513

Yi, Y. and La, S. (2004). What influences the relationship between customer satisfaction and repurchase intention? Investigating the effects of adjusted expectations and customer loyalty. Psychology \& Marketing, 21(5), 351-373. http://dx.doi.org/10.1002/mar.20009

Yoo, B. and Donthu, N. (2001). Developing and validating a multidimensional consumer based brand equity scale. Journal of Business Research, 52(1), 1-14. http://dx.doi.org/10.1016/S0148-2963(99)00098-3

$\mathrm{Yu}, \mathrm{Y}$. T. and Alison, A. (2001). The contribution of emotional satisfaction to consumer loyalty. International Journal of Service Industry Management, 12(3), 234-250. http://dx.doi.org/10.1108/09564230110393239 
Zeithaml, V.A. (1988). Consumer perceptions of price, quality, and value: A meansend model and synthesis of evidence. Journal of Marketing, 52(7), 2-21. http://dx.doi.org/10.2307/1251446

Zeithaml, V.A., Berry, L.L. and Parasuraman, A.A. (1996). The behavioural consequences of service quality. Journal of Marketing, 60(2), 31-46. http://dx.doi.org/10.2307/1251929

Zhanga, S., van Doornb, J., \& Leeflang, P. S.H. (2014). Does the importance of value, brand and relationship equity for customer loyalty differ between Eastern and Western cultures? International Business Review, 23(1), 284-292. http://dx.doi.org/10.1016/j.ibusrev.2013.05.002 
